\title{
Chemical Characterization, Antioxidant, Anticancer and Hypolipidimic Activities of Chamomile (Matricaria chamomilla L.)
}

\author{
Maher H Helal ${ }^{1}$, Sherif EA Badr ${ }^{2 *}$ and Shymaa A AbedElaaty ${ }^{1}$ \\ ${ }^{1}$ Faculty of Science, Helwan University, Cairo, Egypt \\ ${ }^{2}$ Regional Center for Food \& Feed "RCFF", Agricultural Research Center "ARC", Giza, Egypt \\ ${ }^{\star}$ Corresponding author: Sherif El-Sayed Aly Badr, NMR Lab, Regional Center for Food and Feed (RCFF), Agriculture Research Center (ARC), Egypt
}

Received: September 28, 2021; Accepted: October 04, 2021; Published: October 12, 2021

\begin{abstract}
Highest grade chamomile is widely cultivated in Egypt and is one of the most important medicinal plants. The current study reported newly specification and characterization of chamomile flower. Results revealed that iron, flavonoid content, total phenolic, total antioxidant capacity, saponins, glucan and mannan were 788 ppm, $467.1 \mathrm{mg} / 100 \mathrm{~g}$ QE, $556.44 \mathrm{mg} / 100 \mathrm{~g}$ GAE, $785.88 \mathrm{mg} / 100 \mathrm{~g}$ ACE, 2.385\%, $79.44 \mathrm{~g} / \mathrm{Kg}$ and 83.65 g/Kg, respectively. GC/MS analysis of chamomile methanolic extract ensured the presence of thirty seven compounds: salinomycin (32.09\%), uvaol (5.81\%), terpinoline (1.95\%), humulene $(0.72 \%)$ and curcuminol $(1.06 \%)$. Fatty acid profile indicated the existence of linoleic acid (17.78\%) and palmitic acid (15.91\%). DPPH and ABTS assays were applied to monitor the antioxidant capacity of chamomile extract. Assessment of antitumor activity of methanolic extract of chamomile flowers were fruitful with recorded $\mathrm{IC}_{50}=15.2 \mu \mathrm{g} / \mathrm{ml}$ and $\mathrm{IC}_{50}=33 \mu \mathrm{g} / \mathrm{ml}$ for intestinal (Caco-2) and colon (HCT) carcinoma cell lines.

Aqueous chamomile extract was prepared and screened for its cholesterol lowering property In-vivo. Rats were fed hyperlipidemic diet and administered aqueous chamomile extract for eight weeks. There was a decrease in cholesterol level in chamomile treated rat group comparable to hyperlipidemic group. Chamomile extracts reduced cholesterol and LDL levels. Increase of HDL level was observed in chamomile administered group in comparison with positive control. Non-significant difference in triglyceride level existed between negative and positive controls. Administration of chamomile had no effect in altering triglyceride.
\end{abstract}

The study presented newly results concerning chamomile regarding its high iron and biologically active phytochemical contents, antitumour potency against two life threatening cancer cell lines and hypocholesterolimic effect.

Keywords: Chamomile flowers, Chemical analysis, Methanolic and aqueous extracts, Antioxidant and antitumor activities, In-vivo study

\section{Introduction}

According to the World Health Organization (WHO) over three quarters of the world's population relies mainly on the use of medicinal plants for their health care. From approximately 250,000 species of higher plants on Earth, research suggests that even two thirds of them have medicinal value [1a,b]. Chamomile or Matricaria chamomilla L., from the family Compositae, was an important medicinal herb in ancient Egypt, Greece and Rome [2]. Chamomile is sometimes known as "the plant doctor", because it is thought to help the growth and health of many other plants, especially ones that produce essential oils. It is thought to increase production of those oils, making certain herbs, like mints (spearmint, sage, oregano) and basil stronger in scent and flavor [3-5].

Flowers are one of the most important parts of a plant that has polyphenols, carotenoids, and many bioactive compounds. The flowers of many plants are consumed as tea because of their antioxidant properties and their important role in the human diet [6]. Common chamomile is one of the most popular flowers used in different fields (such as cosmetics, food and beverage production, medicine, and aromatherapy). In addition to being used in traditional medicine, it is also used for tea and vitamin supplements [7]. Chamomile plant extracts, one of the most consumed herbal teas, have also been reported to many biological activities [8]. Chamomile is known for it's as anti-inflammatory, anti-diarrhea [9], antioxidant [10], anti-cancer [11], neuro-protective [12], anti-allergic [13] and antimicrobial [14] effects. It also improves cardiac health [15]. Chamomile is an annual herbaceous plant and is Generally Regarded as Safe (GRAS) because it neither contains toxic compounds nor represents any acute toxicity for humans and animals [16]. Chamomile is known for its richness in phenolic compounds believed to be responsible for its biological activities [17]. It contains phenolic compounds such as the flavonoids apigenin, quercetin, patuletin and luteolin, glucosides and coumarins [18]. As far as could be ascertained, there is no published report in the literature on the hypolipidimic activity of chamomile flower.

The present study has been designed to define chemical constituents of chamomile flowers and monitoring the effectiveness of methanolic and aqueous extracts by In-Vitro and In-Vivo assays. 


\section{Materials and Methods}

\section{Plant Material}

Chamomile was purchased from Beni-Suef governorate, located $120 \mathrm{~km}$ south Cairo on the west bank of the Nile River during the year 2020. The plant specimen was identified by the Botany Department, Faculty of Science, Helwan University. The flowers were solar dried in solar energy department of National Research Centre, Giza, Egypt. After drying process, seeds of flowers were separated and grounded to finely coarse powder and kept in plastic bags till the completion of the work.

\section{Nutritional Evaluation of Chamomile Flower Seeds powder}

Ash, silica, fats, fibres, moisture and crude protein were determined according to the [19]. Carbohydrate content was calculated by difference [20]. Minerals measurement of $\mathrm{Fe}, \mathrm{Zn}$ and $\mathrm{Cu}$ was conducted according to the [21]. The amino acids were estimated by the [22] protocol. Total aflatoxin was performed according to [23].

\section{Phytochemical Analysis}

Total flavonoid was determined according to [24], total phenolic compounds [25] and total antioxidant capacity [26]. Saponin content was determined by double solvent extraction gravimetric [27] and mannan [28]. HPLC determination of beta-glucan was conducted according to [29].

\section{Methanolic Extract of Chamomile flowers Powder}

Two hundred grams of chamomile flowers powder were exhaustively extracted with two liters of $80 \%$ methanol (v/v) using a Turrax mixer set at $11,000 \mathrm{rpm}$ for 20 seconds. After full extraction, the extract was then centrifuged at $3000 \mathrm{rpm}$ for 30 minutes to remove the residues [30]. The methanol extract was concentrated in vacuo at $45^{\circ} \mathrm{C}$ and partitioned with chloroform. Chloroform extract was then evaporated to dryness in vacuo, affording an oily dark brown green extract (15.3 g). Oil stored refrigerated until fatty acid profile, GC/MS analysis, screening of antioxidant activities as well as In-Vitro assays.

\section{Fatty Acid Composition}

Fatty acid of methanolic extract was Trans esterified into their corresponding fatty acid methyl esters as described by [31].

\section{GC/MS Identification}

Characterizations of methanol extract components by GC/MS technique [32] was performed at the Regional Center for Food and Feed (RCFF) using GC (Agilent Technologies 7890A) equipped with a mass-selective detector operating by HP- $5 \mathrm{~ms}$ capillary column (30 $\mu \mathrm{m} \times 0.25 \mathrm{~mm}$ i.d. and $0.25 \mu \mathrm{m}$ film thickness). The temperature was increased from $80^{\circ} \mathrm{C}$ to $230^{\circ} \mathrm{C}$ with rate of $3^{\circ} \mathrm{C} \mathrm{min}^{-1}$. Carrier gas was helium at a flow rate of $1 \mathrm{ml} \mathrm{min}^{-1}$.

Identification of secondary metabolites was performed by comparing mass spectra and retention time with those of authentic standards and by matching with the database of National Institute of Standard and Technology (NIST).

\section{Antioxidant Activity}

Antioxidant activity of methanolic chamomile flowers extract was measured using 2, 2-Diphenyl-1-picryl-hydrazyl (DPPH) [33] and 2, 2-azino-bis (3- ethylbenzothiazoline-6-sulphonic acid (ABTS) assay [34].

\section{Antitumor Activity}

Anticancer study was assessed using SRB method at National Cancer Institute, Cairo, Egypt. Colon (HCT) and intestine $\left(\mathrm{Caco}^{-2}\right)$ carcinoma cell lines were chosen to monitor anticancer activity of methanolic chamomile extract. Samples were prepared by dissolving 1:1 Stock solution and stored at $-20^{\circ} \mathrm{C}$ in dimethylsulfoxide (DMSO) at $100 \mathrm{mM}$. Different concentrations of the drug were used $(5,12.5,25,50 \mu \mathrm{g} / \mathrm{ml})$.

SRB is a protein stain that binds to the amino groups of intracellular proteins under mildly acidic conditions to provide a sensitive index of cellular protein content [35].

\section{Calculation}

Percentage of cell survival was calculated as follows:

Surviving fraction $=$ OD $($ treated cells $) / O D$ (control cells)

The $\mathrm{IC}_{50}$ values (the concentrations of resveratrol required to produce $50 \%$ inhibition of cell growth) were also calculated.

\section{Aqueous Extract of Chamomile flowers Powder}

Fifty grams of chamomile flowers powder was extracted in boiled water $(1 \mathrm{~L})$ with stirring for $30 \mathrm{~min}$. After cooling, the aqueous solution was filtered to afford aqueous extract about $890 \mathrm{~g}$.

\section{In-vivo Assay}

A study was carried out to evaluate the biological impacts for chamomile flowers aqueous extract on lipid profile for rats of hypercholesterolemia. Cholesterol, triglyceride, HDL, LDL and body weight were monitored after eight weeks experimental period.

\section{Experimental Design}

Biological experiment lasted for eight weeks was assessed using 27 male albino rats weighing $90 \pm 10$ g. Rats were divided into three groups of nine each. Control group (I), Hyperlipidemic group (II) and hyperlipidemic with administration of aqueous chamomile extract group (III). The rats were housed in stainless steel cages and maintained at $22-24^{\circ} \mathrm{C}$ with relative humidity $45-55 \%$. Diet and water were provided ad-libitum. Adaptation time was three days using barley as the sole diet. At zero time, after 4 weeks and at 8- weeks (end of experiment) rats of each group weighted individually and anaesthetized with $\mathrm{CO}_{2}$ and blood samples were collected via the retro-orbital plexus [36,37]. Serum was obtained by centrifuging at $3000 \mathrm{rpm}$ for $15 \mathrm{~min}$ [38] separated and kept at $4{ }^{\circ} \mathrm{C}$ until biochemical analysis of triglycerides, cholesterol [39], High Density Lipoprotein (HDL) [40] and Low Density Lipoprotein (LDL) [41].

\section{Diets}

\section{Three Types of diets (I, II and III) were Prepared as Follows}

Group fed a standard diet (I) served as negative control formulated according to NRC, 1995 [42] and drunk tap water. Treated group (II) "positive control" fed lipid enriched diet included $20 \%$ soya bean oil as fat source to prepare high fat diet and drunk tap water, and group (III) 
fed lipid enriched diet (II) and supplied with freshly prepared aqueous extract of chamomile flowers as the sole source of fluid. All diets were analyzed for moisture, crude protein, fiber, fat and ash [43].

\section{Reagents and Standards}

All chemicals and solvents were obtained from Merck and Sigma Aldrich, and they were analytical grade. Ultrapure water was used throughout this study (Millipore Direct Q, Bedford, MA, USA). Calibration graphs were constructed using standard solutions at different gallic acid and trolox levels to determine antioxidant activity and total phenolic content in the samples. BioTek Eon Elisa Microplate spectrophotometer was used for all measurements.

\section{Statistical Analysis}

Analysis of variance (Multivariate) and Duncan's test were conducted using a statistical Analyses software SPSS (2017) [44]. A probability to $(\mathrm{P} \leq 0.05)$ was used to establish the statistical significance.

\section{Results and Discussion}

\section{Chemical Composition of Dried Chamomile Flowers Seeds Powder}

\section{Proximate Analysis}

As shown in Table 1, fat and protein were $7.8 \%$ and $15.3 \%$ respectively. Chamomile is packed with metal enzymes iron, zinc and copper which play roles in Anemia of Iron deficiency, growth and good cholesterol respectively. Iron valued (788 ppm), zinc (47.5 ppm) and copper (7.96 ppm). The presence of these nutrients was most abundant that reported with [45] and may interpret chamomile flowers as a complement in management of human related ailments and promotion of health. Ash and moisture contents were 9.5 and $9.6 \%$, respectively. It was reported that ash and moisture in chamomile didn't exceed $13 \%$ and $12 \%$, respectively [46]. The results showed that chamomile flower seeds powder are rich with carbohydrate (54.74\%). Carbohydrates are the most abundant nutrient in several fruit peels [47].

\section{Amino Acids Profile}

Amino acids were determined and presented in Table 2. Proline $(1.07 \mathrm{mg} / 100 \mathrm{~g})$, glutamic $(2.08 \mathrm{mg} / 100 \mathrm{~g})$ and aspartic $(1.41 \mathrm{mg} / 100$

Table 1: Chemical analysis of chamomile flowers (g/100 g dried flowers seeds powder).

\begin{tabular}{|c|c|}
\hline Parameter & Results (\%) \\
\hline Ash & 9.5 \\
\hline Fat & 7.8 \\
\hline Moisture & 9.6 \\
\hline Protein & 15.3 \\
\hline Silica & 3.06 \\
\hline Total Carbohydrates & 54.74 \\
\hline Mineral & $(\mathbf{p p m})$ \\
\hline Iron & 788 \\
\hline Zinc & 47.5 \\
\hline Copper & 7.96 \\
\hline
\end{tabular}

Table 2: Amino acid profile of dried chamomile flower powder.

\begin{tabular}{|c|c|}
\hline Amino acid & Result (mg/100 g)\% \\
\hline \multicolumn{2}{|l|}{ Essential amino acids } \\
\hline Hisitidine & 0.34 \\
\hline Isoleucine & 0.56 \\
\hline Leucine & 0.85 \\
\hline Lysine & 0.76 \\
\hline Methionine & 0.34 \\
\hline Phenylalanine & 0.62 \\
\hline Therionine & 0.56 \\
\hline Valine & 0.72 \\
\hline Total essential amino acids & 4.75 \\
\hline \multicolumn{2}{|l|}{ Non-essential amino acids } \\
\hline Aspartic & 1.41 \\
\hline Serine & 0.66 \\
\hline Glutamic & 2.08 \\
\hline Proline & 1.07 \\
\hline Glycine & 0.75 \\
\hline Alanine & 0.78 \\
\hline Cysteine & 0.25 \\
\hline Tyrosine & 0.47 \\
\hline Argnine & 0.80 \\
\hline otal non-essential amino acids & 8.27 \\
\hline
\end{tabular}

g) acids and were the most abundant in the dried flowers seeds powder as compared with obtained with [48]. Essential and non -essential amino acids are detected in the powder.

The dried chamomile flower seeds powder was free from aflatoxin and ocratoxin and safety usage for the different assays. Chamomile is an annual herbaceous plant and is Generally Regarded as Safe (GRAS) because it neither contains toxic compounds nor represents any acute toxicity for humans and animals (Tolouee et al., 2010).

\section{Phytochemical Quantification}

Total antioxidant capacity, total flavonoid, total phenolic, saponins, $\beta$-Glucan and mannan were $785.88 \mathrm{mg} / 100 \mathrm{~g} \mathrm{AAE}, 467.1$ $\mathrm{mg} / 100 \mathrm{~g} \mathrm{QE}, 556.44 \mathrm{mg} / 100 \mathrm{~g} \mathrm{GAE}, 2.385 \%, 79.44 \mathrm{~g} / \mathrm{Kg}$ and $83.65 \mathrm{~g} /$ $\mathrm{Kg}$, respectively (Table 3 ).

The total phenolic contents were determined as $\mathrm{mg}$ gallic acid/100 g chamomile flowers seeds on comparison with a

Table 3: Phytochemical analysis of chamomile extract

\begin{tabular}{|c|c|}
\hline Parameter & Results \\
\hline Total antioxidant & $785.88 \mathrm{mg} / 100 \mathrm{~g} \mathrm{AAE}$ \\
\hline Total flavonoid & $467.1 \mathrm{mg} / 100 \mathrm{~g} \mathrm{QE}$ \\
\hline Total phenolic & $556.44 \mathrm{mg} / 100 \mathrm{~g} \mathrm{GAE}$ \\
\hline Saponin & $2.385 \%$ \\
\hline$\beta$-Glucan & $79.44 \mathrm{~g} / \mathrm{Kg}$ \\
\hline Mannan & $83.65 \mathrm{~g} / \mathrm{Kg}$ \\
\hline
\end{tabular}


standard gallic acid curve. The chamomile flowers seeds showed a high total phenolic content (556.44 $\mathrm{mg}$ gallic acid/100 g). The total flavonoid content $(467.1 \mathrm{mg}$ quercetin/100 g) was determined as mg quercetin $/ 100 \mathrm{~g}$ chamomile flowers seeds after comparison with the quercetin calibration curve. The extract also has $2.385 \%$ of crude saponin. As per literature, these compounds can be found not only in the eatable part of the fruits but also in the noneatable portions and have different biological activities such as antioxidant, antihepatotoxic effects and anti-inflammatory activity [48-50a]. Plant secondary metabolites such as polyphenols, play an important role in the defense against free radicals. Medicinal plant parts (roots, leaves, stems, flowers and fruits) are commonly rich in phenolic compounds, such as flavonoids, tannins, stilbenes, coumarins, lignans [50b]. The total antioxidant activity of the chamomile flowers seeds was $785.88 \mathrm{mg}$ Ascorbic Acid Equivalence (AAE)/100 g. The total antioxidant capacity may due to its flavonoids and phenol contents of chamomile flower seeds. The antioxidant properties of polyphenols are due to their redox properties, which allow them to act as reducing agents, hydrogen donators, metal chelators and single oxygen quenchers. Polyphenolics exhibit a wide range of biological effects including antibacterial, antiinflammatory, antiallergic, hepato-protective, antithrombotic, antiviral, anticarcinogenic and vasodilatory actions; many of these biological functions have been attributed to their free radical scavenging and antioxidant activity [51a]. $\beta$-Glucan and mannan were79.44 $\mathrm{g} / \mathrm{Kg}$ and $83.65 \mathrm{~g} / \mathrm{Kg}$, respectively; as shown in Table 3 increase the immunity toward blood diseases [51b].

Table 4: Fatty acid of chamomile extract.

\begin{tabular}{|c|c|c|}
\hline Fatty acid & Name & Concentration \\
\hline C10:0 & Capric acid & $3.45 \%$ \\
\hline $\mathrm{C} 12: 0$ & Lauric acid & $0.73 \%$ \\
\hline $\mathrm{C} 14: 0$ & Myristic acid & $4.03 \%$ \\
\hline $\mathrm{C} 16: 0$ & Palmitic acid & $15.91 \%$ \\
\hline $\mathrm{C} 16: 1 \omega 9$ & Palmatolic acid & $3.11 \%$ \\
\hline $\mathrm{C} 17: 0$ & Heptadecanoic acid & $1.19 \%$ \\
\hline C18:0 & Stearic acid & $5.40 \%$ \\
\hline $\mathrm{C} 18: 1 \omega 9$ & Oleic acid & $9.64 \%$ \\
\hline $\mathrm{C} 18: 1 \omega 7$ & Vaccinic acid & $0.47 \%$ \\
\hline $\mathrm{C} 18: 2 \omega 6$ & Linoleic acid & $17.78 \%$ \\
\hline $\mathrm{C} 18: 2 \omega 4$ & PUSFA Mixture mixture acid mixture & $13.90 \%$ \\
\hline $\mathrm{C} 18: 3 \omega 3$ & Linolenic acid & $5.71 \%$ \\
\hline $\mathrm{C} 18: 4 \omega 3$ & Alpha octadecatetraenoic & $1.04 \%$ \\
\hline C20:0 & Arachidic acid & $1.83 \%$ \\
\hline $\mathrm{C} 20: 2 \omega 6$ & PUSFA Mixture & $12.41 \%$ \\
\hline $\mathrm{C} 20: 3 \omega 6$ & Eicosatrienoic acid & $0.63 \%$ \\
\hline $\mathrm{C} 20: 4 \omega 6$ & Arachidonic acid & $1.13 \%$ \\
\hline $\mathrm{C} 22: 4 \omega 3$ & Eicosatrienoic acid & $0.59 \%$ \\
\hline C22:0 & Behenic acid & $1.02 \%$ \\
\hline Non Identified fatty acids & & $0.03 \%$ \\
\hline
\end{tabular}

\section{Fatty Acid Profile of Methanolic Extract}

Fatty acid of chamomile extract is presented in Table 3. Linoleic acid (17.78\%), palmitic acid (15.91\%) and oleic acid (9.64\%). Saturated and unsaturated fatty acid existed in chamomile extract (Table 4 ).

\section{GC/MS Identification of Methanolic Extract of Chamomile} Seeds Powder

Table 5: GC/MS analysis of chamomile methanolic extract.

\begin{tabular}{|c|c|c|c|}
\hline NO & RT (min) & NAME & AREA SUM (\%) \\
\hline 1 & 7.5 & Cedrenol & 1.53 \\
\hline 2 & 7.7 & Terpinolene & 1.95 \\
\hline 3 & 7.95 & Elemene- $\Upsilon$ & 0.48 \\
\hline 4 & 8.16 & -Patchoulene $\Upsilon$ & 0.76 \\
\hline 5 & 8.33 & B-Gurjunene & 1,08 \\
\hline 6 & 9.34 & Aromandendrene & 2.49 \\
\hline 7 & 10.028 & $( \pm)$-Cadinene & 0.95 \\
\hline 8 & 11.006 & -Selinener & 25.2 \\
\hline 9 & 11.18 & $\begin{array}{c}\text { 7,8-Dihydroxy-4- } \\
\text { methylcoumarin-3-actic acid }\end{array}$ & 4.69 \\
\hline 10 & 11.32 & Uvaol & 5.81 \\
\hline 11 & 12.3 & Salinomycin & 32.09 \\
\hline 12 & 12.37 & Lutein & 0.41 \\
\hline 13 & 12.69 & Manumycin A & 0.41 \\
\hline 14 & 12.93 & (+)-Isovalencenol & 1.35 \\
\hline 15 & 13.1 & Curcumenol & 1.06 \\
\hline 16 & 13.3 & Geranyl- $\boldsymbol{\alpha}$-terpinene & 1.21 \\
\hline 17 & 13.45 & $\alpha$-Vetivol & 0.32 \\
\hline 18 & 13.65 & Retinal & 0.85 \\
\hline 19 & 13.96 & Ylangenol & 1.1 \\
\hline 20 & 14.17 & Geranyllinalool & 0.57 \\
\hline 21 & 14.53 & -Humulene $\beta$ & 0.72 \\
\hline 22 & 14.72 & Valerenol & 0.53 \\
\hline 23 & 14.94 & -Himachalene $\Upsilon$ & 0.58 \\
\hline 24 & 15.18 & -3 Arachidonic acid ethyl ester $\omega$ & 3.12 \\
\hline 25 & 15.64 & Isovitexin & 0.38 \\
\hline 26 & 15.64 & -Bisabolola & 0.38 \\
\hline 27 & 16.16 & Digoxigenin & 1.22 \\
\hline 28 & 16.37 & (-)-Globulol & 3.44 \\
\hline 29 & 17.14 & Squalene & 0.4 \\
\hline 30 & 17.5 & -Iononea & 0.4 \\
\hline 31 & 17.8 & All-trans-farnesyl acetate & 0.4 \\
\hline 32 & 18.15 & -Terpinyl acetatea & 0.33 \\
\hline 33 & 18.42 & Betulin & 0.35 \\
\hline 34 & 18.775 & 3-Carene & 0.74 \\
\hline 35 & 19.1 & Phenol,2,3,5-trimethyl & 0.41 \\
\hline 36 & 19.23 & $2^{\prime}, 3^{\prime}$-Dimethoxyyflavanone & 0.33 \\
\hline 37 & 24.8 & Isomyristic acid & 1.29 \\
\hline
\end{tabular}


GC/MS chromatogram elucidated the existence of thirty seven compounds: terpinoline, $\alpha$-bisabolol, salinomycin, uvaol, curcuminol and humulene. Data clarified that most of the identified compounds belonged to the class of sesquiterpenes. Our results are in accordance with WHO (1999) that sesquiterpenes formed up to $50 \%$ of chamomile oil (Table 5).

\section{Antioxidant Activity of Chamomile Methanolic Extract by DPPH and ABTS Assays}

To assess antioxidant activity of chamomile extract, DPPH and ABTS methods were applied. DPPH is a stable free radical with absorption band at $515 \mathrm{~nm}$. It loses this absorption when reduced by antioxidant such as phenolic compound and plant extracts (Table 6) [52].

Ascorbic acid and chamomile were prepared in concentration range of $0.195-50 \mathrm{mg} / \mathrm{ml}$ and $3.125-50 \mathrm{mg} / \mathrm{ml}$, respectively. DDPH scavenging activity of chamomile extract ranged between $89.514 \%$ at $50 \mathrm{mg} / \mathrm{ml}$ to $20.971 \%$ at $3.125 \mathrm{mg} / \mathrm{ml}$, While for ABTS scavenging activity ranged between $91.885 \%$ at $50 \mathrm{mg} / \mathrm{ml}$ to $36.065 \%$ at $3.125 \mathrm{mg}$ /

Table 6: Antioxidant activity of chamomile extract.

\begin{tabular}{|c|c|c|c|}
\hline Sample & Concentration $(\mathrm{mg} / \mathrm{ml})$ & DPPH\% & ABTS\% \\
\hline \multirow{9}{*}{ Ascorbic } & 50 & 91.219 & 94.714 \\
\hline & 25 & 92.583 & 94.884 \\
\hline & 12.5 & 92.497 & 94.884 \\
\hline & 6.25 & 92.412 & 94.884 \\
\hline & 3.125 & 92.497 & 96.419 \\
\hline & 1.562 & 92.412 & - \\
\hline & 0.781 & 92.327 & - \\
\hline & 0.39 & 84.057 & - \\
\hline & 0.195 & 43.478 & - \\
\hline \multirow{5}{*}{ Chamomile } & 50 & 89.514 & 91.885 \\
\hline & 25 & 89.343 & 94.918 \\
\hline & 12.5 & 68.968 & 94.344 \\
\hline & 6.25 & 36.913 & 60.327 \\
\hline & 3.125 & 20.971 & 36.065 \\
\hline
\end{tabular}

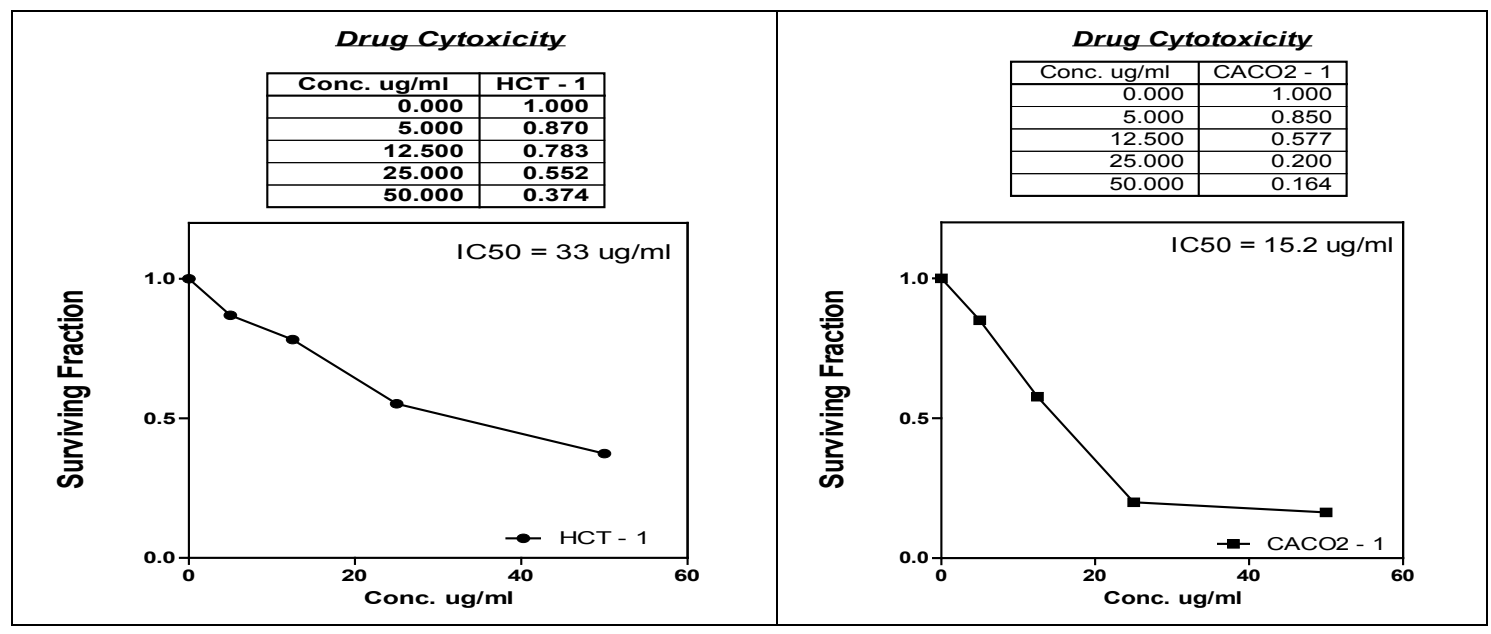

Figure 1: Antitumour activity of methanolic chamomile extract. $\mathrm{ml}$. it was obvious that the antioxidant activity increased with increase in chamomile concentration.

DPPH and ABTS assays ascertained the antioxidant capacity of chamomile extract as monitored in our results. These findings are consistent with Lim et al. (2007). As a result, antioxidant of chamomile extract may be mainly related to high level of phenol and flavonoid contents [53]. Cited that phenols and flavonoids contributed to antioxidant activity of extracts. An important compound detected in chamomile is terpinoline reputable as antioxidant [54], antiinflammatory [55] and chemotherapeutic [56]. It exerted effective DPPH-scavenging activity (Kim et al., 2004) and may lower LDL oxidation (Tisserand and Young, 2014). The presence of $\beta$-humulene acted as antioxidant in chamomile oil increased the value of this herbal plant packed with naturally occurring sesquiterpenes. Described the antioxidant potential of $\beta$-humulene against free radicals [57].

\section{Antitumor Activity of Chamomile Methanolic Extract}

Antitumor activity for methanolic extract of chamomile (Table 7 and Figure 1) against human colon (HCT) and intestinal $\left(\mathrm{Caco}^{-2}\right)$ carcinoma cell lines were tested. Antioxidants, which prevent the oxidative degradation of free radicals in the human body and help, prevent or reduce different diseases such as cancer, cardiovascular, and neurodegenerative diseases, have an important role in protecting human health [58a]. It is known that antioxidants in natural foods with antioxidant potential are safer and more beneficial compared to many synthetic antioxidants. Therefore, the antioxidant potentials of many vegetables, fruits, leaves, roots, spics, and herbs are still being investigated today. In-vitro studies ascertained the impact of chamomile extract on the viability of colon (HCT) and intestine ( $\mathrm{Caco}^{-}$ $\left.{ }^{2}\right)$ cancer cells with $\mathrm{IC}_{50}$ of 33 and $15.2 \mu \mathrm{g} / \mathrm{ml}$, respectively. The viability and survival rates of cancer cell lines decreased as the concentration

Table 7: Antitumor activity of chamomile extract against intestinal and colon carcinoma cell lines.

\begin{tabular}{|c|c|c|}
\hline Methanolic Extract & $\mathrm{CaCo}^{-2}$ & HCT \\
\hline $\mathrm{IC}_{50}$ & 15.2 & 33 \\
\hline
\end{tabular}


of chamomile extract increased, proving anti-tumor potency of chamomile that may be due to presence of sesquiterpenes. Activity of chamomile extract may refer to uvaol that affected positively conditions of colonic inflammation by suppressing macrophage infiltration and pro-inflammatory cytokine release In-vivo [58b].

Another article, declared that uvaol, natural triterpene, exerted remarkable selective anticancer effect in human hepatocarcinoma HepG2 cells [59]. An increase in apoptosis rate, down regulation of the AKT/PI3K signaling pathway and reduction in Reactive Oxygen Species (ROS) level in HepG2 cells were observed. The role of uvaol on human astrocytoma line $1321 \mathrm{~N} 1$ through maximizing rate of apoptotic process via activation of the JNK pathway [60] and stated that uvaol had effect on MCF-7 cells by decreasing reactive oxygen species and cell viability.

Table 8: Effect of aqueous chamomile extract on hyperlipidemia.

\begin{tabular}{|c|c|c|c|c|}
\hline \multirow{2}{*}{ Parameter } & \multirow{2}{*}{ Group } & \multicolumn{3}{|c|}{ Time } \\
\hline & & Zero time & After 4-weeks & After 8-weeks \\
\hline \multirow{3}{*}{ Cholesterol } & I & ${ }^{\mathrm{B}} 79.11_{c} \pm 1.52$ & ${ }^{\mathrm{B}} 91.11_{\mathrm{b}} \pm 2.04$ & ${ }^{\mathrm{B}} 105.78 \mathrm{a} \pm 1.24$ \\
\hline & II & ${ }^{\mathrm{A}} 90.89_{c} \pm 3.04$ & ${ }^{\mathrm{A}} 103.89_{\mathrm{b}} \pm 1.83$ & ${ }^{\mathrm{A}} 118.899_{\mathrm{a}} \pm 1.79$ \\
\hline & III & ${ }^{A} 87.56$ a \pm 1.20 & ${ }^{\mathrm{c}} 80.89_{b} \pm 1.21$ & $\mathrm{c}_{73.00} \pm 0.75$ \\
\hline \multirow{3}{*}{ HDL } & I & ${ }^{\mathrm{A}} 40.899_{\mathrm{a}} \pm 1.45$ & ${ }^{\mathrm{B}} 26.78_{\mathrm{b}} \pm 0.66$ & ${ }^{\mathrm{B}} 28.44_{\mathrm{b}} \pm 0.93$ \\
\hline & II & ${ }^{C_{2} 2.56_{a} \pm 0.50}$ & ${ }^{\mathrm{c}} 16.44_{\mathrm{b}} \pm 0.53$ & ${ }^{c} 14.56_{b} \pm 0.73$ \\
\hline & III & ${ }^{\mathrm{B}} 28.11_{\mathrm{c}} \pm 0.86$ & ${ }^{\mathrm{A}} 38.11_{\mathrm{b}} \pm 1.03$ & ${ }^{\mathrm{A}} 44.44 \mathrm{a} \pm 1.47$ \\
\hline \multirow{3}{*}{ LDL } & I & ${ }^{\mathrm{A}} 42.00_{\mathrm{c}} \pm 0.41$ & ${ }^{\mathrm{A}} 44.56_{\mathrm{b}} \pm 0.99$ & ${ }^{\mathrm{B}} 48.67{ }_{\mathrm{a}} \pm 0.37$ \\
\hline & II & ${ }^{\mathrm{A}} 41.56_{\mathrm{b}} \pm 0.63$ & ${ }^{\mathrm{A}} 44.33_{\mathrm{b}} \pm 1.01$ & ${ }^{\mathrm{A}} 52.33 \mathrm{a} \pm 1.46$ \\
\hline & III & ${ }^{\mathrm{A}} 42.44_{\mathrm{a}} \pm 1.14$ & ${ }^{\mathrm{B}} 38.78_{\mathrm{b}} \pm 0.55$ & ${ }^{c} 33.67_{c} \pm 0.53$ \\
\hline \multirow{3}{*}{ Triglycerides } & I & ${ }^{\mathrm{A}} 186.22_{\mathrm{b}} \pm 1.33$ & ${ }^{\mathrm{B}} 181.33_{\mathrm{b}} \pm 3.27$ & ${ }^{\mathrm{B}} 211.44_{\mathrm{a}} \pm 2.89$ \\
\hline & II & ${ }^{\mathrm{B}} 176.00_{\mathrm{c}} \pm 2.37$ & ${ }^{\mathrm{B}} 187.22_{\mathrm{b}} \pm 2.03$ & ${ }^{\mathrm{B}} 206.22{ }_{\mathrm{a}} \pm 1.98$ \\
\hline & III & ${ }^{\mathrm{B}} 172.67_{\mathrm{c}} \pm 2.13$ & ${ }^{\mathrm{A}} 203.33_{\mathrm{b}} \pm 4.00$ & ${ }^{\mathrm{A}} 232.22{ }_{\mathrm{a}} \pm 3.17$ \\
\hline
\end{tabular}

- Within the same column, various superscript letters indicate significant differences (Duncan, $P<0.05$ )

- Capital letters were used to compare three groups vertically.

- Group I (Control group).

- Group II (hyperlipidemic group)

- Group III (hyperlipidemic diet and aqueous chamomile extract)
Another effective compound in chamomile extract is salinomycin and was cited that salinomycin fight breast cancer stem cells in mice 100 times more than anticancer drug paclitaxel. Due to its ability to targeting cancer stem cells, salinomycin is the key valuable compound in pharmaceutical company [61].

\section{Hypolipidimic Effect of Chamomile Aqueous Extract}

Aqueous extract of chamomile flowers dried powder was prepared and screened for its cholesterol lowering property in rats fed hyperlipidimic diet for eight weeks. There was a decrease in cholesterol and LDL levels in chamomile treated group comparable to hyperlipidemic group (Table 8). Increase of HDL level was observed in chamomile administered group in comparison with positive control. Non-significant difference in triglyceride level existed between negative and positive controls. Administration of chamomile didn't alter triglyceride level. Lowering of cholesterol may be due to existence of curcuminol possessing antioxidant and hypolipidimic properties. Chamomile aqueous extract contained $\beta$-glucan considered as water soluble dietary fiber. Lowering of cholesterol level by chamomile extract may be contributed to $\beta$-glucan that formed viscous layer in small intestine [62], this layer attenuated and minimized uptake of dietary cholesterol with increased production of bile acid and reduced blood cholesterol level. According to [63], consumption of oat $\beta$-glucan lowered blood cholesterol and reduced risk of heart coronary diseases. $\beta$-glucan availability is greater when consumed in beverage other than solid matrix [64]. Also, the presence of mannan, another dietary fiber, induced hypolipidemia by modulation of gut microbiota, increasing bile acid excretion and decreasing plasma cholesterol [65].

\section{Body Weight Monitoring of Treated Groups}

As shown in (Figure 2), body weight of rat group fed high fat diet and administered aqueous chamomile extract showed decreased weight gain in comparison with positive hyperlipidemic group. Our results are in accordance with [66] who stated that a reduction in weight of hypercholesterolimic rats fed glucomannan compared to control diet may be due to low daily food intake and the presence of insoluble fiber in the gastrointestinal tract.

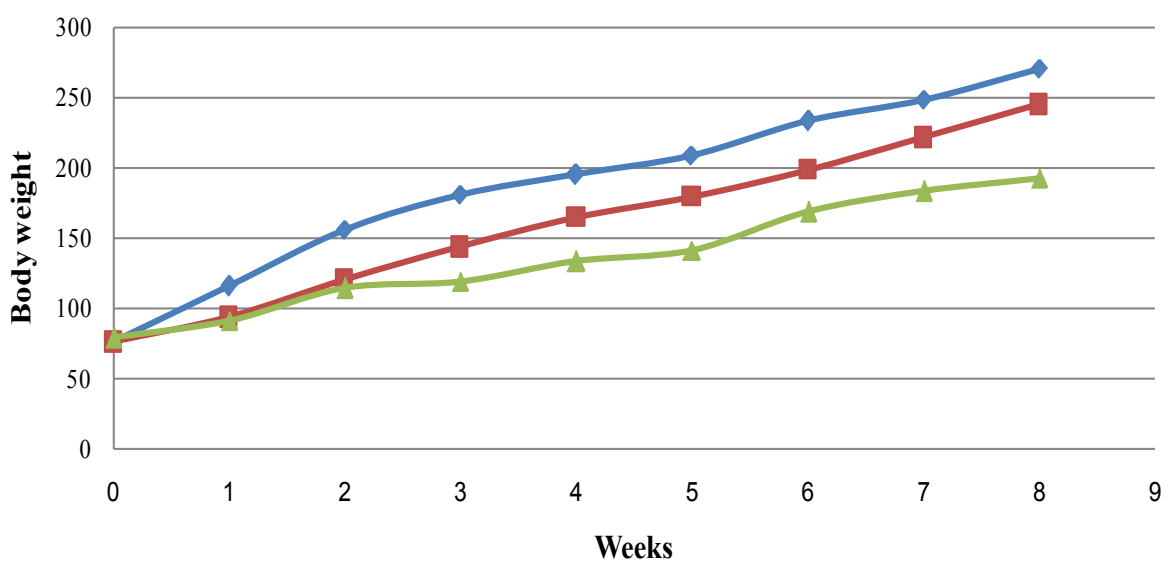

$\neg$ Controlgroup $\quad-$ Hyperlipidemic diet group $\rightarrow-$ (hyperlipidemic diet + chamomile) group

Figure 2: Effect of chamomile aqueous extract on rat body weight. 


\section{Conclusion}

This study could be concluded that Aqueous extract of chamomile flower seeds is a good nutritious source of carbohydrates, protein, crude fiber, essential and non-essential amino acids which are vital for human nutrition and maintains a good health. Chemical characterization of chamomile ascertained for the first time the presence of $\beta$-glucan and is appreciable for its lipid lowering properties. This herbal medicine acquired special interest as natural source of important phytochemicals (mannan, Glucan, flavonoids, phenols and sesquiterpines) which play important roles in scavenging the free radicals which strongly needed to fight ailments. Aqueous extract showed very high improving HDL and reducing LDL and total cholesterol profile for hypercholesteremic albino rats. Economic advantages of chamomile tea recommended to be applied in food processing and appear its vital role in therapeutic nutrition especially with hypercholesteremic, heart disease and weight control patients. Chamomile was reported to induce apoptosis in cancer cells Also, chamomile is packed with metal enzymes iron, zinc and copper which play roles in Anemia of Iron deficiency, growth and good cholesterol respectively. Further studies will be conducted to assess the bioavailability of these minerals in a trial to be supplemented as a compliment in malnutrition treatment.

\section{Acknowledgment}

This research was funded by the Regional Centre for Food and Feed (RCFF), Agriculture Research Center (ARC), Giza, Egypt and Animal House of National Research Center (NRC).

\section{References}

1. (a) Joy PP, Thomas J, Mathew S, Skaria BP (1998) In Medicinal Plants, Bose TK. (Ed). Naya Prokash publishers India 449-632; (b) Králová K, Masarovičová E (2010) Plants for the future. Ecological Chemistry and Engineering 13: 1179-1207.

2. Srivastava JK, Shankar E, Gupta S (2010) Chamomile: a herbal medicine of the past with bright future. Molecular Medicine Reports 3: 895-901. [crossref]

3. Omid Beigi R (2000) Produce of the drug plants, 1st edn, Nashr Press 2: 424-430

4. Zargari A (1991) Medical plants, 5th edn vol.2, Tehran University Press 942.

5. Kulisic T, Radonic A, Katalinic V (2004) Use of different methods for testing antioxidative of oregano essential oil. Food Chemistry 85: 633-640.

6. Sotiropoulou NS, Megremi SF, Tarantilis P (2020) Evaluation of antioxidant activity, toxicity, and phenolic profile of aqueous extracts of chamomile (Matricaria chamomilla L) and sage (Salvia officinalis L) prepared at different temperatures. Applied Sciences 10: 2270 .

7. Al-Snafi AE (2018) Traditional uses of Iraqi medicinal plants. Journal of Pharmacy 8: 32-95.

8. Zlabur JS, Zutic I, Radman S, Plesa M, Brncic M, et al. (2020) Effect of different green extraction methods and solvents on bioactive components of chamomile (Matricaria chamomilla L) flowers. Molecules 25: 810 .

9. Peña D, de Montes Oca N, Rojas S, Parra A, García G (2006) Anti-inflammatory and anti-diarrheic activity of Isocarpha cubana Blake. Pharmacologyon line 3: 744-749.

10. Sebai H, Jabri M A, Souli A, Rtibi K, Selmi S, Tebourbi O, et al. (2014) Antidiarrheal and antioxidant activities of chamomile (Matricaria recutita L) decoction extract in rats. J Ethnopharmacol 152: 327-332. [crossref]

11. Patel D, Shukla S, Gupta S (2007) Apigenin and cancer chemoprevention: progress, potential and promise. Int J Oncol 30: 233-245. [crossref]

12. Ranpariya V, Parmar S, Sheth N, Chandrashekhar V (2011) Neuroprotective activity of Matricaria recutita against fluoride induced stress in rats. Pharm Biol 49: 696-701. [crossref]
13. Chandrashekhar V, Halagali K, Nidavani R, Shalavadi MH, Biradar BS, et al. (2011) Anti-allergic activity of German chamomile (Matricariarecutita L) in mast cell mediated allergy model. J Ethnopharmacol 137: 336-340. [crossref]

14. Silva N, Barbosa L, Seito L, Fernandes Junior A (2012) Antimicrobial activity and phytochemical analysis of crude extracts and essential oils from medicinal plants. Nat Prod Res 26: 1510-1514. [crossref]

15. Gould L, Reddy CR, Gomprecht RF (1973) Cardiac effects of chamomile tea. J Clin Pharmacol 13: 475-479. [crossref]

16. Tolouee M, Alinezhad S, Saberi R, Eslamifar A, Zad SJ, et al. (2010) Effect of Matricaria chamomilla L. flower essential oil on the growth and ultrastructure of Aspergillus niger van Tieghem. International Journal of Food Microbiology 139: 127160. [crossref]

17. Guimarães R, Barros L, Dueñas M, Calhelha RC, Carvalho AM, et al. (2013) Infusion and decoction of wild German chamomile: bioactivity and characterization of organic acids and phenolic compounds. Food Chemistry 136: 947-954. [crossref]

18. McKay DL, Blumberg JB (2006) A review of the bioactive and potential health benefits of chamomile tea (Matricaria recutita L). Phytotherapy Research 20: 519-530. [crossref]

19. AOAC (1995) Association of Official Agriculture Chemists. Official Methods of Analysis. 16th ed., Washington D.C. USA.

20. Sara YH, Nafisa MEH, Amro BH, Mohamed ME, Elfadil EB (2008) Nutritional evaluation and physicochemical properties of processed pumpkin (Telfairia ocidentalis Hook) seed flour. Pakistan J of Nutr 7: 330-334.

21. AOAC Association of Official Agriculture Chemists (2002) Official Methods of Analysis. 17th ed., Washington D.C. USA 1: 40-41.

22. AOAC (2005) Association of Official Agriculture Chemists. Official Methods of Analysis. 18th ed., Washington D.C. USA.

23. AOAC (2012) Official Method of Analysis, Association of official Analytical Chemistry. International No.994.12.chapter 4, P.9-13.19th Edition.

24. Arvouet-Grand A, Vennat B, Pourrat A, Legret P (1994) Standardization dun extrait de propolis et identification des principaux constituants. Journal de Pharmacie de Belgique 49: 462-468. [crossref]

25. Singleton VL, Orthofer R, Lamuela-Raventos RM (1999) Analysis of total phenols and other oxidation substrates and antioxidants by means of Folin-Ciocalteu reagent. Methods in Enzymology 299: 152-178.

26. Gioda Alain, Maria del Rosario Prieto (1999) HISTOIRE DES SÉCHERESSES ANDINES POTOSI, EL Nrfio Er LE PETIT ÂGE GLACIAI. La Météorologie 8' série - no 27.

27. Obdoni BO, Ochuko PO (2002) Phytochemical studies and comparative efficacy of the crude extracts of some Homostatic plants in Edo and Delta States of Nigeria. Global J Pure Appl Sci 8b: 203-208.

28. Moreira LRS, Filho EXF (2008) An overview of mannan structure and mannan degrading enzyme systems. Appl Microbiol Biotechnol 79: 165-178. [crossref]

29. Pérez-Vendrell AM, Guasch J, Francesch M, Molina-Cano JL, Brufau J (1995) Determination of beta-(1-3),(1-4)-D-glucans in barley by reversed-phase. Cromatogr A 718: 291-297. [crossref]

30. Medina-Medrano JR, Almaraz-Abarca N, González-Elizondo MS, Uribe-Soto JN, González-Valdez LS, et al. (2015) Phenolic constituents and antioxidant properties of five wild species of Physalis (Solan aceae). Bot Stud 56: 24. [crossref]

31. AOAC (2012) Association of Official Agriculture Chemists. Official Methods of Analysis. 17th ed., Washington D.C. USA. Chapter 4. 969.3 and 991.39 fatty acids in Oils and Fats preparation of Methyl Esters Boron Tri- Flouride- AOAC-IUPAC Method Codex- Adopted- AOAC Method 41: 19-20.

32. Patricia MS, Migdalia M, Juan AP, Mario S, Víctor H, et al (2013) Gas Chromatography-Mass Spectrometry Study from the Leaves Fractions Obtained of Vernonanthura patens (Kunth) H. Rob. Int J of Org Chem 3: 105-119.

33. Lee Chang Y, Dae-OkKim, Seung Weon Jeong (2003) Antioxidant capacity of phenolic phytochemicals from various cultivars of plums. Food Chemistry 81: 321-326.

34. Tagliazucchi D, Ahmed Helal, Elena Verzelloni, Angela Conte (2016) Bovine milk antioxidant properties: effect of in vitro digestion and identification of antioxidant compounds. Dairy Science \& Technology 96: 657-676. 
35. Vichai V, Kirtikara K (2006) Sulforhodamine B. colorimetric assay for cytotoxicity screening. Nat Protoc 1: 1112-1116. [crossref]

36. Saka WA, Akhigbe RE, Popoola OT, Oyekunle OS (2012) Changes in serum electrolytes, urea, and creatinine in Aloe vera-treated rats. Journal of Pharmacology 4: 78-81. [crossref]

37. Sherif EA Badr, Eman S Ramis, Ola A Wahdan, Dina M Sakr, Hanan MA Elghandour (2017) Evaluation of protein quality, phytochemical characterization and the effect of soaking and roasting process on raw apricot kernels. The first international conference of Nutrition, Hurghada, the Egyptian Nutrition Society 253-287.

38. Akhigbe RE, Azeez OM, Ige SF, Oyeyipo IP, Ajao FO, et al. (2008) Hemorheological effect of long-term administration of oral contraceptive in rats. Int J Pharmacol 4: 403-406.

39. Walter GG, Narayanan S, Wisser H, Zawta B (2001) Samples from the patient to the laboratory: the impact of preanalytical variables on the quality of laboratory results. 2ed edition. Wiley-VCH Verlag GmbH \& Co. KGaA, Weinheim.

40. Friedewald WT, Levy RI, Fredrickson DS (1972) Estimation of the con centration of low-density lipoprotein cholesterol in plasma, without use of the preparative ultracentrifuge. Clin Chem 18: 499-450. [crossref]

41. Levy RI (1981) Review: cholesterol, lipoproteins, approtreins and heart disease, present status and future prospects. Clin Chem 27: 653-662. [crossref]

42. NRC (1995) National Research Council. Nutrient requirements of laboratory animals, 5th ed. Chapter 3, PP 80-102. National Academy Press, Washinngton, DC.

43. AOAC $(2005,2007)$ Association of Official of Analytical Chemists, Of ficial method of analysis 18th Ed., Association of Official Analytical

44. Chemists, Arlington, VA. SPSS (2017) SPSS/PC+V.25.0, Base Manual for IBM PC/ $\mathrm{XT} / \mathrm{AT}$ and PS/25. Marija and Morusis, Chicago, IL, Soil Science Society of America, Inc.

45. Suaad Abd Al-Mahdi Abd Noor (2020) Studying the Pharmaceutical; Elements and Bio-Effect of the Chamomile Plants as a Medicinal Plant. Systematic Review Pharmacy 11: 733-741.

46. World Health Organization (WHO) monographs on selected medicinal plants (Volume 1). Geneva, 1999.

47. Maniyan A, John R, Mathew A (2015) Evaluation of Fruit Peels for Some Selected Nutritional and Anti-Nutritional Factors. Emer Life Sci Res 1: 13-19.

48. Aboul-Enein AM, Salama ZA, Gaafar AA, Aly HF, Abou-Elella FA, et al. (2016) Identification of phenolic compounds from banana peel (Musaparadaisica L) as antioxidant and antimicrobial agents. J Chem Pharm Res 8: 46-55.

49. Suttirak W, Manurakchinakorn S (2014) In vitro antioxidant properties of mangosteen peel extract. J Food Sci Technol 51: 3546-3558. [crossref]

50. a) Wu SJ, Tsai JY, Chang SP, Lin DL, Wang SS, et al. (2006) Super critical carbon dioxide extract exhibits enhanced antioxidant and anti-inflammatory activities of Physalis peruviana. J Ethnopharmacol 108: 407-413. [crossref] b) Cai YZ, Luo Q, Sun M Corke H (2004) Antioxidant activity and phenolic compounds of 112 Chinese medicinal plants associated with anticancer. Life Sci 74: 2157-2184. [crossref]
51. a) Soobrattee M, Neergheen VS, Luximon-Ramma A, Aruoma OI, Bahorum T (2005) Phenolics as potential antioxidant therapeutic agents: Mechanism and actions. Mut Res 579: 200-213. [crossref] b) Eken A, Ünlü-Endirlik B, Baldemir A, İlgün S, Soykut B. (2016) Antioxidant capacity and metal content of Physalis peruviana L. fruit sold in markets. J Clin Anal Med 7: 291-294.

52. Lim YY, Quah EPL (2007) Antioxidant properties of diferent cultivars of Portu laca oleracea. Food Chem 103: 734-740.

53. Formisano C, Delfine S, Oliviero F, Tenore GC, Rigano D, et al. (2015) Correlation among environmental factors, chemical composition and antioxidative properties of essential oil and extracts of chamomile (Matricaria chamomilla L) collected in Molise (south-central Italy). Industrial Crops and Products 63: 256-263.

54. Kim HJ, Chen F, Wu C, Wang X, Jin Z (2004) Evaluation of antioxidant activity of Australian tea tree oil and its components. J Agric Food Chem 52: 2849-2854. [crossref]

55. Tisserand R, Young R (2014) Essential Oil Safety, 2nd ed.; Elsevier: Edinburgh, UK.

56. Sawamura M, Sun SH, Ozaki K, Ishikawa J, Ukeda H (1999) Inhibitory effects of Citrus essential oils and their components on the formation of $\mathrm{N}$-nitrosodimethylamine. $J$ Agric Food Chem 47: 4868-4872. [crossref]

57. Gunawan IWG, Bawa-Putra AA, Widihati IAG (2016) The response to oxidative stress humulene Hibiscus L. leaf on the activity of 8-OHdG levels pancreatic $\beta$ - cells in diabetic rats. Biomedical and Pharmacology 9: 433-441.

58. a) Kurt BZ, Gazioglu I, Sevgi E, Sonmez F (2018) Anticholinesterase, antioxidant, antiaflatoxigenic activities of ten edible wild plants from Ordu area, Turkey. Iranian Journal of Pharmaceutical Research 17: 1047-1056. [crossref]. b) Shi-yun Du, Heifeng Huang, Xian qian Li, Hai-tao Xiao (2020) Anti-inflammation properties of uvaol on DSS-induced colitis and LPS-stimulated macrophages. Chin Med 15: 43.

59. Bonel-perez, Gloria C, perez-jimenez, Amalia, Rufino-Palomares Eva E, GrisCardenas Isabel, et al. (2020) Antiproliferative and pro-apoptotic effect of uvao in human hepatocarcinoma HepG2 cells by affecting G0/G1 cell cycle arrest, ROS production and AKT/PI3K signaling pathway. Molecules 25: 4254. [crossref]

60. Allouche Y, Warieta F, Campos M, Beltran G, Gaforio JJ (2011) Antioxidant, antiproliferative and pro-apoptotic capacities of pentacyclic triterpenes on MCF-7 human breast cancer cells and their effects on DNA damage. J Agric Food Chem 59: 121-130. [crossref]

61. Gupta P, Onder Tamer T, Jiang Guozhi, Lander, Eric S (2009) Identification of selection inhibitors of cancer stem cells by throughout screening Cell 138: 645-659. [crossref]

62. Rondanelli M, Oppizzi A (2009) The biological activity of beta glucan. Minerva Med 100: 237-245. [crossref]

63. EFSA (2010) Scientific opinion on the substantiation of a healthy claim related to oat Betaglucan and lowering blood cholesterol. EFSA Journal 8: 1885.

64. Queenan KM, Stewart ML, Smith KN, Thomas W, Fulcher RG, et al. (2007) Concentrated oat beta glucan lowers cholesterol in a randomized controlled trial. Nutr J 6: 6. [crossref]

65. Lisa H, Saeed K and Vaneesa VH (2018) Dietary mannan oligosaccharide modulates gut microbiota, and decrease cholesterol and atherosclerosis development. Mol Nutr Food Res 62: 1700942. [crossref]

66. Gallaher CM, Munion J, Hesslink R, Wise J, Gallaher DD (2000) Cholesterol reduction by glucomannan and chitosan in rats. J Nutr 130: 2753-2759. [crossref]

Citation:

Helal MH, Badr SEA, AbedElaaty SA (2021) Chemical Characterization, Antioxidant, Anticancer and Hypolipidimic Activities of Chamomile (Matricaria chamomilla L.). Nutr Res Food Sci J Volume 4(2): 1-8. 